University of Nebraska - Lincoln

DigitalCommons@University of Nebraska - Lincoln

Agronomy \& Horticulture - Faculty Publications

Agronomy and Horticulture Department

2017

\title{
Genotype, environment, seeding rate, and top-dressed nitrogen effects on end-use quality of modern Nebraska winter wheat
}

\author{
Madhav Bhatta \\ University of Nebraska-Lincoln, madhav.bhatta@huskers.unl.edu \\ Teshome Regassa \\ University of Nebraska-Lincoln, tregassa2@unl.edu \\ Devin J. Rose \\ University of Nebraska-Lincoln, drose3@unl.edu \\ P. Stephen Baenziger \\ University of Nebraska-Lincoln, pbaenziger1@unl.edu \\ Kent M. Eskridge \\ University of Nebraska-Lincoln, keskridge1@unl.edu
}

See next page for additional authors

Follow this and additional works at: https://digitalcommons.unl.edu/agronomyfacpub

Part of the Agricultural Science Commons, Agriculture Commons, Agronomy and Crop Sciences Commons, Botany Commons, Horticulture Commons, Other Plant Sciences Commons, and the Plant Biology Commons

Bhatta, Madhav; Regassa, Teshome; Rose, Devin J.; Baenziger, P. Stephen; Eskridge, Kent M.; Santra, Dipak K.; and Poudel, Rachana, "Genotype, environment, seeding rate, and top-dressed nitrogen effects on enduse quality of modern Nebraska winter wheat" (2017). Agronomy \& Horticulture -- Faculty Publications. 1102.

https://digitalcommons.unl.edu/agronomyfacpub/1102

This Article is brought to you for free and open access by the Agronomy and Horticulture Department at DigitalCommons@University of Nebraska - Lincoln. It has been accepted for inclusion in Agronomy \& Horticulture -Faculty Publications by an authorized administrator of DigitalCommons@University of Nebraska - Lincoln. 


\section{Authors}

Madhav Bhatta, Teshome Regassa, Devin J. Rose, P. Stephen Baenziger, Kent M. Eskridge, Dipak K.

Santra, and Rachana Poudel 


\title{
Genotype, environment, seeding rate, and top-dressed nitrogen effects on end-use quality of modern Nebraska winter wheat
}

\author{
Madhav Bhatta, ${ }^{1}$ Teshome Regassa, ${ }^{1}$ Devin J. Rose, ${ }^{2}$ \\ P. Stephen Baenziger, ${ }^{1}$ Kent M. Eskridge, ${ }^{3}$ \\ Dipak K. Santra, ${ }^{4}$ and Rachana Poudel ${ }^{2}$
}

\footnotetext{
1 Department of Agronomy and Horticulture, University of Nebraska-Lincoln, Lincoln, NE, USA

2 Food Science and Technology Department, University of Nebraska-Lincoln, Lincoln, NE, USA

3 Department of Statistics, University of Nebraska-Lincoln, Lincoln, NE, USA

4 Panhandle Research and Extension Center, University of Nebraska-Lincoln, Scottsbluff, NE, USA

Corresponding author - T. Regassa, Department of Agronomy and Horticulture, University of Nebraska-Lincoln, 175 Keim Hall, Lincoln, NE 68583, USA; email tregassa2@unl.edu
}

\begin{abstract}
Background: Fine-tuning production inputs such as seeding rate, nitrogen $(\mathrm{N})$, and genotype may improve end-use quality of hard red winter wheat (Triticum aestivium L.) when growing conditions are unpredictable. Studies were conducted at the Agronomy Research Farm (ARF; Lincoln, NE, USA) and the High Plains Agricultural Laboratory (HPAL; Sidney, NE, USA) in 2014 and 2015 in Nebraska, USA, to determine the effects of genotype (6), environment (4), seeding rate (3), and flag leaf top-dressed $\mathrm{N}\left(0\right.$ and $\left.34 \mathrm{~kg} \mathrm{~N} \mathrm{ha}^{-1}\right)$ on the end-use quality of winter wheat.

Results: End-use quality traits were influenced by environment, genotype, seeding rate, top-dressed N, and their interactions. Mixograph parameters had a strong correlation with grain volume weight and flour yield. Doubling the recommended
\end{abstract}


seeding rate and $\mathrm{N}$ at the flag leaf stage increased grain protein content by $8.1 \%$ in 2014 and $1.5 \%$ in 2015 at ARF and 4.2\% in 2014 and $8.4 \%$ in 2015 at HPAL.

Conclusion: The key finding of this research is that increasing seeding rates up to double the current recommendations with $\mathrm{N}$ at the flag leaf stage improved most of the end-use quality traits. This will have a significant effect on the premium for protein a farmer could receive when marketing wheat.

Keywords: grain protein, end-use quality traits, wheat marketing, dough rheology

\section{Introduction}

Wheat (Triticum aestivum L.) is an economically important cereal crop with unique functional proteins. It is a staple food for more than one-third of the world's population and supplies nearly $20 \%$ of food calories. ${ }^{1}$ Hard red winter wheat constitutes $40 \%$ of the total wheat production in the USA. ${ }^{2}$ Hard red winter wheat produced in the Great Plains of the USA is inherently variable in quality characteristics both within and across crop years. ${ }^{3}$ One of the important agronomic management practices that affects end-use quality of wheat is seeding rate. Increased seeding rate was found to decrease mixing tolerance, and to increase flour yield and dough development time. ${ }^{4,5}$ Some studies, however, reported no effect of seeding rate on grain protein content, ${ }^{6}$ whereas others reported reduced ${ }^{4,5}$ or increased ${ }^{7}$ grain protein content with increase in seeding rate. Despite the inconsistencies in response to grain protein content, the fact that seeding rate can be easily manipulated by producers 8,9 and has shown a significant effect on end-use quality ${ }^{4}$ makes it a factor of interest.

Nitrogen $(\mathrm{N})$ is one of the most essential nutrients for proper growth and grain quality of winter wheat. ${ }^{10} \mathrm{~N}$ application in wheat increases grain protein content. ${ }^{11,12} \mathrm{~A}$ positive linear relationship has been found between $\mathrm{N}$ application and wheat bread-making quality. ${ }^{13}$ The amount of grain protein is strongly influenced by the rate of $\mathrm{N}$ application, ${ }^{14}$ and increased $\mathrm{N}$ application rate often results in increased grain protein content. ${ }^{15}$ For increasing $\mathrm{N}$ fertilization recovery, it is important to apply $\mathrm{N}$ when $\mathrm{N}$ requirement is high for plants. ${ }^{16} \mathrm{~N}$ application at anthesis was found to be the most efficient application time specifically when the intent was to increase grain protein content in wheat. ${ }^{17}$

Milling quality is determined by grain volume weight and flour yield, whereas baking quality is related to grain protein content, Mixograph dough development time, mixing tolerance and water absorption. ${ }^{18} \mathrm{Grain}$ protein content is an integral factor in determining bread-making quality. ${ }^{19}$ Use of modern genotypes and appropriate management practices have been shown to improve end-use quality, ${ }^{4,8}$ and previous research needs to be updated as new genotypes and production systems are developed. 
Understanding the response of genotype to key components of the production system such as seeding rate and $\mathrm{N}$ is important across all production environments. Although the effects of seeding rate and $\mathrm{N}$ application on agronomic performance of wheat have been studied previously, there is a lack of knowledge regarding the response of additional top-dressed $\mathrm{N}$ application at the flag leaf stage and little information regarding the response of seeding rate on end-use quality of winter wheat. Therefore, the objective of this experiment was to determine the effects of genotype, environment, seeding rate, top-dressed $\mathrm{N}$ at the flag leaf stage and their interactions on the end-use quality of modern Nebraska winter wheat genotypes.

\section{Materials and Methods}

\section{Grain sample production}

Field experiments were conducted under rainfed conditions in 2014 and 2015 at the High Plains Agricultural Laboratory (HPAL) in Sidney, Nebraska (coordinates: $41^{\circ} 13^{\prime} 47^{\prime \prime} \mathrm{N}, 103^{\circ} \mathrm{O}^{\prime} 4^{\prime \prime} \mathrm{W}$ ), and the Agronomy Research Farm (ARF) in Lincoln, Nebraska (coordinates: $40^{\circ} 51^{\prime} 15.077^{\prime \prime} \mathrm{N}, 96^{\circ} 36^{\prime} 46.828^{\prime \prime} \mathrm{W}$ ).

The experimental design was a randomized complete block with a split factorial arrangement replicated four times. Two $\mathrm{N}$ treatments ( 0 and 34 $\mathrm{kg} \mathrm{N} \mathrm{ha-1}$ applied at the flag leaf stage, Feekes 9) were assigned to the whole plots (this treatment was in addition to the recommended $\mathrm{N}$ fertilizer applied at planting with $56 \mathrm{~kg} \mathrm{~N} \mathrm{ha}^{-1}$ ) and factorial combinations of three seeding rates $(1 / 2,1$, and 2 times the recommended seeding rate for each site), and six genotypes were assigned to the split plots (1.8m $\times$ $7.6 \mathrm{~m}$ at HPAL and $1.5 \mathrm{~m} \times 6.1 \mathrm{~m}$ at ARF). The recommended seeding rates were 186 seeds $\mathrm{m}^{-2}$ at HPAL and 252 seeds $\mathrm{m}^{-2}$ at ARF, corresponding to 50 and $67 \mathrm{~kg} \mathrm{ha}^{-1}$ as described in Bhatta et al. ${ }^{20}$ The genotypes were 'Freeman', 'Millennium', 'Overland', 'Pronghorn', 'Robidoux' and 'Settler CL', as described in Poudel et al. ${ }^{21}$ Plot samples collected at harvest were used for end-use quality analysis.

\section{End-use quality analyses}

Grain protein content $\left(\mathrm{g} \mathrm{kg}^{-1}\right)$ and moisture content $\left(\mathrm{g} \mathrm{H}_{2} \mathrm{O} \mathrm{kg}-1\right)$ were determined using a near-infrared reflectance analyzer (DA 7250, Perten Instruments, Springfield, IL, USA) calibrated respectively to combustion analysis using a LECOFP528 (Approved Methods 46-30.1, AACC International 2013) ${ }^{22}$ and gravimetric method (Approved Methods 44-19.01, AACC International 2013). ${ }^{22}$ Grain volume weight $\left(\mathrm{kg} \mathrm{hL}^{-1}\right)$ was recovered from a specialized plot combine harvester (SPC-40, ALMACO, IA at ARF or Delta combine, 
Wintersteiger, UT, USA, at HPAL), and it was reported in $\mathrm{kg} \mathrm{hL}^{-1}$ after converting from pounds per bushels of the harvested grain.

Aliquots of grain portions $(50 \mathrm{~g})$ were taken from each plot and tempered to a moisture basis of $152 \mathrm{~g} \mathrm{H}_{2} \mathrm{O} \mathrm{kg}$-1 for 18-20 h before milling (Approved Methods 26-95.01 AACC International 2013). ${ }^{22}$ Tempered samples were milled in a Quadrumat Junior Mill (CWBranbender Instruments Inc., South Hackensack, NJ, USA). A standard shaker (Strand Shaker Co., Minneapolis, MN, USA) at $225 \mathrm{rpm}$ for $90 \mathrm{~s}$ with the USA standard testing sieve No. 70 with the opening size of $212 \mu \mathrm{m}$ was used to separate flour from bran, and the flour was weighed (Approved Methods 26-21.02, AACC International 2013). ${ }^{22}$ Flour yield was expressed as grams of flour per kilogram of grain. Flour protein content determined by near-infrared analyzer was calibrated to combustion analysis using a LECO FP528 (Approved Methods 46-30.1, AACC International 2013) ${ }^{22}$ and moisture content was calibrated to standard gravimetric method (Approved Methods 44-19.01, AACC International 2013). ${ }^{22}$

To test the mixing properties of a resulting dough and estimate end-use quality, a $10 \mathrm{~g}$ flour sample (adjusted to $140 \mathrm{~g} \mathrm{H}_{2} \mathrm{O} \mathrm{kg}{ }^{-1}$ moisture) was run in a Mixograph (National Manufacturing, Lincoln, NE, USA) (Approved Methods 54-40.02, AACC International 201322 for end-use quality analysis. Water absorption was determined using the regression equation provided in the method (water absorption percent $=1.5 \times$ protein at $140 \mathrm{~g} \mathrm{H}_{2} \mathrm{O} \mathrm{kg}{ }^{-1}$ moisture basis+43.6) (Approved Methods 54-40.02, AACC International 2013).22 Mixograph mixing time was fixed to $8 \mathrm{~min}$ and data were analyzed using Mixsmart software (National Manufacturing). Midline peak time (dough development time) was recorded as the time in minutes required for optimum development of dough. Midline peak value (dough strength) was calculated as the height of the curve at midline peak time and indicated dough strength. Midline curve tail area (resistance to dough extension) was the area under the midline curve to the end of the analysis ( $8 \mathrm{~min}$ ) and showed resistance to dough extension (\%TQ $\times$ min, where TQ is torque). Mixing tolerance was scored using a scale from 0 to 7 based on the comparison against standard Mixograph curves in the Nebraska Wheat Quality Laboratory. The higher number denotes greater tolerance of dough to overmixing (Approved Methods 54-40.02, AACC International, 2013).22

\section{Data analysis}

Data were analyzed using SAS 9.4 software. ${ }^{23} \mathrm{~A}$ combined analysis was performed to test the effects of environment, $N$, seeding rate, genotype and their interactions. Analysis of variance was calculated by using PROCMIXED considering each site-year as a separate environment. Environment, N, seeding rate, genotype and their interactions were tested as fixed effects. Blocks were considered random. The LSMEAN statement was used for calculating 
treatment means, and mean separation was done using Fisher's protected LSD test at the $5 \%$ level of significance using the simulation option available in the LINES statement of PROC GLIMMIX. Pearson correlations between grain protein content, flour yield, grain volume weight and Mixograph parameters were computed on least squares means using PROC CORR.

\section{Results and Discussion}

\section{Analysis of variance}

A combined analysis of variance identified significant effects of environment, genotype, $\mathrm{N}$ and seeding rate on end-use quality parameters (Table 1). Significant four-way (environment $\times N \times$ seeding rate $\times$ genotype) interactions were observed for grain volume weight and dough development

Table 1. Analysis of variance with mean squares for the selected end-use quality parameters of six genotypes grown at three seeding rates with two nitrogen $(\mathrm{N})$ treatments in four environments in Nebraska

\begin{tabular}{|c|c|c|c|c|c|c|c|c|}
\hline Source of variance & d.f. & $\begin{array}{l}\text { Grain } \\
\text { protein } \\
\text { content } \\
\left(\mathrm{g} \mathrm{kg}^{-1}\right)\end{array}$ & $\begin{array}{l}\text { Flour } \\
\text { yield } \\
\left(\mathrm{g} \mathrm{kg}^{-1}\right)\end{array}$ & $\begin{array}{l}\text { Grain } \\
\text { volume } \\
\text { weight } \\
\left(\mathrm{kg} \mathrm{hL}^{-1}\right)\end{array}$ & $\begin{array}{l}\text { Resistance } \\
\text { to dough } \\
\text { extension } \\
\text { (\%TQ× min) }\end{array}$ & $\begin{array}{l}\text { Dough } \\
\text { strength } \\
\text { (\% height) }\end{array}$ & $\begin{array}{c}\text { Dough } \\
\text { development } \\
\text { time (min) }\end{array}$ & $\begin{array}{c}\text { Mixing } \\
\text { tolerance } \\
(0-7)\end{array}$ \\
\hline Environment (ENV) & 3 & 1320 & $26939^{* * *}$ & $2404.1^{* * *}$ & $52851^{*}$ & $1714.4^{*}$ & $35.0^{* * *}$ & $15.5^{\star *}$ \\
\hline Error a & 12 & 731 & 1241.5 & 5.1 & 13072 & 303.9 & 2 & 2.1 \\
\hline Nitrogen (N) & 1 & $3601^{\star *}$ & 11.5 & 19.4 & $17747^{* \star}$ & $447.3^{* *}$ & $15.9^{\star \star *}$ & $6.8^{* *}$ \\
\hline $\mathrm{ENV} \times \mathrm{N}$ & 3 & 393 & $5154.9^{* *}$ & $24.5^{\star}$ & 539.1 & 19.5 & 0.8 & 0.3 \\
\hline Error b & 12 & 233 & 694.2 & 4.6 & 1036.5 & 26.3 & 0.7 & 0.4 \\
\hline Genotype (G) & 5 & $913^{* * *}$ & $3729.2^{* * *}$ & $109.7^{* \star *}$ & $13743^{* * *}$ & $294.2^{* \star *}$ & $55.9^{* * *}$ & $5.9 * * \star$ \\
\hline Seeding rate (SR) & 2 & $1017^{\star \star \star}$ & $3451.5^{\star * *}$ & $60.3^{* * *}$ & $3992.7^{* * *}$ & $94.9 * * *$ & $7.1^{\star \star *}$ & $1.1^{* *}$ \\
\hline$E N V \times G$ & 15 & $371^{* * *}$ & $1488.6^{\star * *}$ & $61.5^{\star * *}$ & $1915.1^{* * *}$ & $41.7^{\star * \star}$ & $8.7^{\star \star \star}$ & $1.8^{\star \star \star}$ \\
\hline$N \times G$ & 5 & 58 & 374.9 & 1.4 & $1227.2^{*}$ & $22.3^{*}$ & 0.3 & 0.1 \\
\hline $\mathrm{ENV} \times \mathrm{SR}$ & 6 & $149 * *$ & 526 & $37.6^{\star * *}$ & 509.8 & $23.6^{*}$ & $1.6^{\star *}$ & 0.1 \\
\hline $\mathrm{N} \times \mathrm{SR}$ & 2 & $168^{*}$ & 57.1 & 2.4 & $1733.8^{*}$ & $40.0^{*}$ & 1.0 & 0.2 \\
\hline $\mathrm{G} \times \mathrm{SR}$ & 10 & 55 & 171.6 & 3.4 & 337.4 & 7.7 & 0.4 & 0.2 \\
\hline$E N V \times N \times G$ & 15 & 39 & 232.4 & 2.0 & $717.8^{\star}$ & $17.3^{*}$ & $0.7^{*}$ & $0.4^{*}$ \\
\hline $\mathrm{ENV} \times \mathrm{N} \times \mathrm{SR}$ & 6 & $84^{*}$ & 215.5 & $4.0^{*}$ & 280.8 & 4.8 & $0.9^{*}$ & 0.3 \\
\hline $\mathrm{ENV} \times \mathrm{G} \times \mathrm{SR}$ & 30 & 20 & 418.6 & $2.8^{*}$ & 321.1 & 7.8 & 0.3 & 0.1 \\
\hline$N \times G \times S R$ & 10 & 42 & 328.4 & 2.3 & 167.3 & 3.4 & 1.0 & 0.3 \\
\hline$E N V \times N \times G \times S R$ & 30 & 16 & 422.2 & $2.9^{*}$ & 173.7 & 4.8 & $0.4^{* *}$ & 0.2 \\
\hline Error c & 408 & 37 & 323.7 & 1.7 & 420.9 & 9.7 & 0.4 & 0.2 \\
\hline
\end{tabular}

Asterisks indicate significance at the ${ }^{*} 0.05,{ }^{* *} 0.01$, and ${ }^{* * *} 0.001$ probability levels, respectively. 
time, but these interactions were small (Table 1) and will not be discussed further. Three-way interactions were observed for grain protein content (environment $\times \mathrm{N} \times$ seeding rate), grain volume weight (environment $\times$ seeding rate $\times$ genotype), resistance to dough extension (environment $\times \mathrm{N} \times$ genotype), dough strength (environment $\times \mathrm{N} \times$ genotype), dough development time (environment $\times \mathrm{N} \times$ seeding rate and environment $\times \mathrm{N} \times$ genotype) and mixing tolerance (environment $\times \mathrm{N} \times$ genotype). Two-way interactions were observed for grain protein content (environment $\times$ genotype), grain volume weight (environment $\times N$ ), flour yield (environment $\times N$ ), resistance to dough extension ( $\mathrm{N} \times$ seeding rate), and dough strength $(\mathrm{N} \times$ seeding rate). The main effect was significant for mixing tolerance (seeding rate) (Table 1). These results provide evidence that end-use quality traits are greatly influenced by environment, genotype, seeding rate and top-dressed $\mathrm{N}$.

\section{Correlations for quality traits and grain yield}

The phenotypic correlations among the eight quality traits and grain yield are presented in Table 2. There was a significant correlation of grain protein content with grain volume weight $\left(r_{p}=-0.22\right)$, mixing tolerance $\left(r_{p}=-0.35\right)$, dough development time $\left(r_{p}=-0.37\right)$, dough strength $\left(r_{p}=0.30\right)$, resistance to dough extension $\left(r_{p}=0.37\right)$ and grain yield $\left(r_{p}=-0.64\right)$. This indicates that these parameters have some level of independence. The negative correlation between grain protein and grain yield is consistent with previous studies in wheat. ${ }^{24}$ In contrast, the negative correlations between these traits are

Table 2. Phenotypic $\left(r_{p}\right)$ correlations among selected end-use quality parameters and grain yield measured from six genotypes grown in four environments in Nebraska

\begin{tabular}{|c|c|c|c|c|c|c|c|c|}
\hline Traita & GP & FWT & GVW & MT & DDT & DS & RDE & GY \\
\hline GP & - & 0.04 & $-0.22^{\star * *}$ & $-0.35^{\star * *}$ & $-0.37^{\star \star *}$ & $0.30^{\star \star *}$ & $0.37^{\star \star \star}$ & $-0.64^{\star \star \star}$ \\
\hline FWT & & - & $0.79 * \star \star$ & $-0.91^{\star \star \star}$ & $-0.89 * \star *$ & $0.88^{\star * \star}$ & $0.95^{\star * \star}$ & 0.10 \\
\hline GVW & & & - & $-0.74^{\star \star \star}$ & $-0.74^{\star * \star}$ & $0.85^{\star * *}$ & $0.84^{\star * \star}$ & $0.58^{* * *}$ \\
\hline MT & & & & - & $0.99^{* * *}$ & $-0.79 * * \star$ & $-0.88^{\star \star \star}$ & 0.17 \\
\hline DDT & & & & & - & $-0.80^{\star \star \star *}$ & $-0.88^{* * \star}$ & 0.24 \\
\hline DS & & & & & & - & $0.97^{* * *}$ & -0.16 \\
\hline $\mathrm{RDE}$ & & & & & & & - & -0.13 \\
\hline GY & & & & & & & & - \\
\hline
\end{tabular}

Asterisks indicate significance at the ${ }^{*} 0.05,{ }^{*} 0.01$, and ${ }^{* *} 0.001$ probability levels, respectively. a. Trait: GP, grain protein content $\left(\mathrm{g} \mathrm{kg}^{-1}\right)$; FWT, flour yield $\left(\mathrm{g} \mathrm{kg}^{-1}\right)_{;}$GVT, grain volume weight $(\mathrm{kg}$ $\left.\mathrm{hL}^{-1}\right)$; $\mathrm{MT}$, mixing tolerance (0-7); DDT, dough development time (min); DS, dough strength (\%); $\mathrm{RDE}$, resistance to dough extension (\%TQ $\times$ min, where TQ is torque); GY, grain yield (Mg ha ${ }^{-1}$ ). 
inconsistent with previous studies in wheat, ${ }^{24}$ and this may be due to inclusion of different genotypes grown in different environments. Negative correlation of grain protein content with grain volume weight, ${ }^{25}$ dough development time ${ }^{24}$ and mixing tolerance ${ }^{24}$ were observed in past research. In contrast, another study found a positive relationship between grain protein content and mixing tolerance, ${ }^{5}$ which may have been due to genotypic differences. All of the low but significant correlations of grain protein content with other quality traits indicate that no single trait was a predictive indicator of end-use quality, and they imply that end-use quality in wheat is defined by a combination of traits.

Flour yield was not correlated with grain protein content, but was positively correlated with grain volume weight, resistance to dough extension and dough strength, and negatively correlated with mixing tolerance and dough development time. Although flour yield was not significantly correlated with protein, flour yield was found to be an important quality trait since it was correlated with other quality traits studied (Table 2). The significant positive correlation between flour yield and grain volume weight was consistent with a previous study. ${ }^{25}$ Grain volume weight was positively correlated with resistance to dough extension, dough strength and grain yield, and negatively correlated with grain protein content, dough development time and mixing tolerance. Grain volume weight and flour yield was positively correlated with grain yield, and improvement of one trait could result in improvement of another. Therefore, these traits should be considered in breeding programs. Milling quality is determined by grain volume weight and flour yield, ${ }^{18}$ and these traits were highly correlated with Mixograph parameters (mixing properties), indicating that Mixograph parameters are also important traits that measure end-use quality of wheat. Mixing tolerance and dough development time were highly positively correlated with each other and negatively correlated with dough strength and resistance to dough extension. Resistance to dough extension and dough strength were highly positively correlated with each other. Pearson correlation coefficients among dough development time, dough strength and resistance to dough extension (Table 2) were similar to previous studies. ${ }^{26}$

\section{Grain protein content}

Grain protein content was significantly influenced by environment, N, seeding rate, genotype, environment $\times$ genotype, and environment $\times \mathrm{N} \times$ seeding rate (Table 1). Grain protein content ranged from 121 to $139 \mathrm{~g} \mathrm{~kg}^{-1}$ across the four environments averaged over genotype (Fig. 1).

A significant environment $\times$ genotype interaction was observed for grain protein content (Table 1). For the genotype Robidoux, grain protein content 


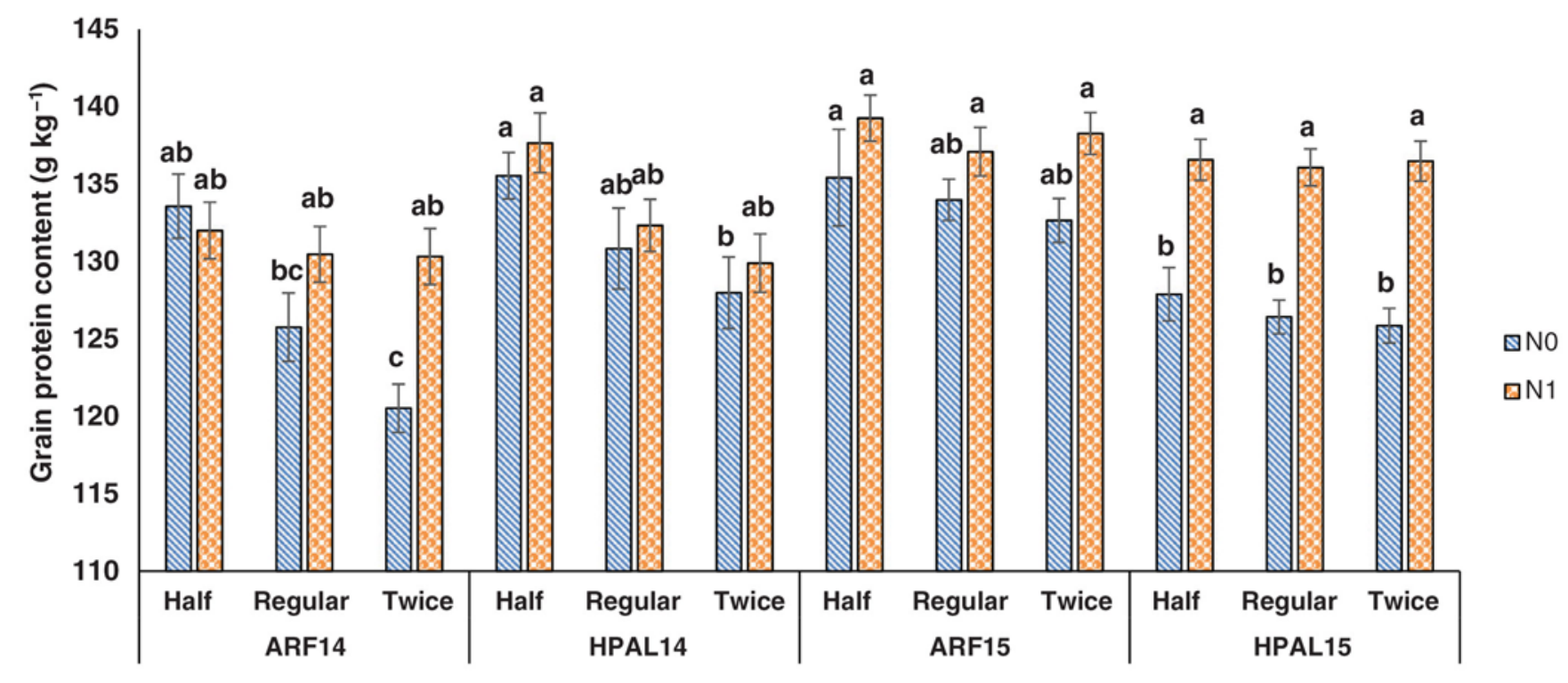

Environment $\times$ Nitrogen $\times$ Seeding rate interaction

Figure 1. Mean grain protein content from interactions among four environments, two nitrogen treatments $(0$ and $34 \mathrm{~kg} \mathrm{~N} \mathrm{ha}^{-1}$ ), and three seeding rates averaged over six genotypes in Nebraska. Seeding rate: half: 93 seeds $\mathrm{m}^{-2}$ and 126 seeds $\mathrm{m}^{-2}$; regular/recommended: 186 seeds $\mathrm{m}^{-2}$ and 252 seeds $\mathrm{m}^{-2}$; twice: 372 seeds $\mathrm{m}^{-2}$ and 504 seeds $\mathrm{m}^{-2}$, respectively at HPAL (High Plains Agricultural Laboratory, Sidney, NE, USA) and at ARF (Agronomy Research Farm, Lincoln, NE, USA) in 2014 and 2015. Nitrogen rates: N0: 0 kg N ha-1 and N1: $34 \mathrm{~kg} \mathrm{~N} \mathrm{ha}^{-1}$.

varied considerably in one environment (ARF15), whereas Freeman, Millennium, Overland, Pronghorn and Settler CL were found to have similar grain protein content across environments (Table 3). This showed that the grain protein content of five genotypes (Freeman, Millennium, Overland and Settler $\mathrm{CL}$ ) were consistent across environments, and genotype Robidoux mainly contributed to the significant interaction between environment and genotype on grain protein content (Table 3 ).

Significant environment $\times \mathrm{N} \times$ seeding rate interactions were observed for grain protein content (Table 1). In general, grain protein content increased due to $\mathrm{N}$ top dressing at the flag leaf stage for all seeding rate and environments, except for half seeding rate at ARF14 (Fig. 1). The increase in grain protein content due to $\mathrm{N}$ could be explained by $\mathrm{N}$ availability to the plant at the critical stage of grain formation. In Idaho, grain protein content linearly increased with the application of $\mathrm{N}$ fertilizer. ${ }^{15}$ Grain protein content decreased with increasing seeding rate (Fig. 1) in two environments (ARF14 and HPAL14) irrespective of N treatment. This was likely due to the effect of competition at the higher plant densities ${ }^{4,5}$ and higher grain yields obtained at higher seeding rates. ${ }^{25}$ However, at ARF15 and HPAL15, an increase in seeding rate did not increase grain protein content regardless of $\mathrm{N}$ treatment. This result could be due to higher rainfall in 2015 especially 
Table 3. Grain protein content and flour yield environment $\times$ genotype interaction means of winter wheat in Nebraska Trait

\begin{tabular}{llllllll} 
& Environment $^{\mathrm{a}}$ & Freeman & Millennium & Overland & Pronghorn & Robidoux & Settler CL \\
\hline Grain protein & ARF14 & $124.6 \mathrm{~b}$ & $131.3 \mathrm{~b}$ & $130.7 \mathrm{~b}$ & $128.8 \mathrm{~b}$ & $127.0 \mathrm{~b}$ & $130.2 \mathrm{~b}$ \\
& HPAL14 & $128.9 \mathrm{~b}$ & $134.5 \mathrm{~b}$ & $131.7 \mathrm{~b}$ & $136.4 \mathrm{ab}$ & $128.2 \mathrm{~b}$ & $134.4 \mathrm{~b}$ \\
& ARF15 & $126.8 \mathrm{~b}$ & $136.2 \mathrm{ab}$ & $134.2 \mathrm{~b}$ & $134.2 \mathrm{~b}$ & $148.6 \mathrm{a}$ & $136.6 \mathrm{ab}$ \\
& HPAL15 & $124.4 \mathrm{~b}$ & $129.8 \mathrm{~b}$ & $131.1 \mathrm{~b}$ & $133.9 \mathrm{~b}$ & $134.3 \mathrm{~b}$ & $135.8 \mathrm{ab}$ \\
\multirow{5}{*}{ Flour yield } & ARF14 & $652.2 \mathrm{~g}-\mathrm{i}$ & $652.7 \mathrm{~g}-\mathrm{i}$ & $658.2 \mathrm{f}-\mathrm{i}$ & $644.6 \mathrm{i}$ & $649.1 \mathrm{hi}$ & $661.2 \mathrm{e}-\mathrm{i}$ \\
& HPAL14 & $655.1 \mathrm{~g}-\mathrm{i}$ & $658.4 \mathrm{e}-\mathrm{i}$ & $656.0 \mathrm{f}-\mathrm{i}$ & $653.5 \mathrm{~g}-\mathrm{i}$ & $656.1 \mathrm{f}-\mathrm{i}$ & $661.8 \mathrm{~d}-\mathrm{i}$ \\
& ARF15 & $667.2 \mathrm{c}-\mathrm{i}$ & $697.0 \mathrm{ab}$ & $699.4 \mathrm{a}$ & $669.9 \mathrm{c}-\mathrm{h}$ & $664.9 \mathrm{c}-\mathrm{i}$ & $665.1 \mathrm{c}-\mathrm{i}$ \\
& HPAL15 & $674.7 \mathrm{~b}-\mathrm{g}$ & $686.7 \mathrm{a}-\mathrm{c}$ & $684.7 \mathrm{a}-\mathrm{d}$ & $672.7 \mathrm{c}-\mathrm{g}$ & $678.2 \mathrm{a}-\mathrm{f}$ & $680.1 \mathrm{a}-\mathrm{e}$ \\
\hline
\end{tabular}

a. Environment: ARF, Agronomy Research Farm, Lincoln, NE, USA; HPAL, High Plains Agricultural Laboratory, Sidney, NE, USA, in 2014 and 2015.

Means followed by the same letter in a given column or row for a trait are not significantly different at $P<0.05$ according to Fisher's LSD test.

Nitrogen rates: N0, $0 \mathrm{~kg} \mathrm{~N} \mathrm{ha}^{-1} ; \mathrm{N} 1,34 \mathrm{~kg} \mathrm{~N} \mathrm{ha}^{-1}$.

Note: $\mathrm{g}-\mathrm{i}, \mathrm{g}$ through $\mathrm{i}$ in a sequence of ghi, and similarly for others.

from flowering to grain filling at both sites. ${ }^{20}$ The result also showed that topdressed $\mathrm{N}$ and twice seeding rate had higher grain protein content compared to no $\mathrm{N}$ and twice seeding rate in all environments, although a significant increase was observed in two environments (ARF14 and HPAL15) (Fig. 1). For instance, doubling the recommended seeding rate and $\mathrm{N}$ top dressing at the flag leaf stage increased grain protein by $8.1 \%$ at ARF14, $1.5 \%$ at ARF15, $4.2 \%$ at HPAL 14 and $8.4 \%$ at HPAL15. Thus grain protein content may be improved from the application of top-dressed $\mathrm{N}$ at the flag leaf stage of wheat planted at a higher seeding rate (Fig. 1) without sacrificing grain yield. ${ }^{20}$

\section{Flour yield}

Flour yield was significantly affected by environment, genotype, seeding rate, environment $\times \mathrm{N}$, and environment $\times$ genotype (Table 1 ).

No significant interaction of seeding rate with genotype or $\mathrm{N}$ or environment was observed (Table 1). Therefore, the main effect of seeding rate was explained further. Increasing seeding rate from half to the recommended seeding rate resulted in increased flour yield $\left(661.9-667.9 \mathrm{~g} \mathrm{~kg}^{-1}\right)$, but no significant change $\left(667.9-670.1 \mathrm{~g} \mathrm{~kg}^{-1}\right)$ when the seeding rate was increased further. This result was similar to previous findings, ${ }^{4,5}$ which found increased flour yield with increased seeding rate up to $65 \mathrm{~kg} \mathrm{ha}^{-1}(245$ seeds $\mathrm{m}^{-2}$ ), i.e. recommended seeding for eastern Nebraska. However, one study found contrary results, where no significant effect of seeding rate on flour 
yield of spring wheat was observed, ${ }^{27}$ and this may have been due to inclusion of different genotypes under study.

A significant environment $\times$ genotype interaction for flour yield was observed (Table 1). This interaction was observed mainly due to change in magnitude of genotypes across the environments as well as a significant increase in four yield for Overland at ARF15 (Table 3). For instance, Overland and Millennium had lower flour yield at ARF14 and HPAL15 but higher flour yield at ARF15 and HPAL15.

A significant environment $\times \mathrm{N}$ interaction was observed for flour yield (Table 1). This interaction was observed due to change in magnitude across the environments as well as increased flour yield due to top-dressed $\mathrm{N}$ application in one environment (HPAL14) (Table 4). In three environments (ARF14, ARF15 and HPAL15) there was no effect of top-dressed $\mathrm{N}$ on flour yield. The result of no influence of $\mathrm{N}$ application on flour yield was consistent with previous findings. ${ }^{27}$

\section{Grain volume weight}

Grain volume weight was influenced by environment, genotype, environment $\times$ genotype, environment $\times \mathrm{N}$, environment $\times$ seeding rate, environment $\times \mathrm{N} \times$ seeding rate, and environment $\times$ genotype $\times$ seeding rate (Table 1). Significant environment $\times \mathrm{N} \times$ seeding rate interactions were observed for grain volume weight, although such interactions were small (Table 1) and, therefore, this will not be explained further. A significant environment $\times \mathrm{N}$ interaction was observed for grain volume weight (Table 1) mainly due to the change in magnitude across the environments (Table 4). No significant effect of top-dressed $\mathrm{N}$ was observed on grain volume weight in

Table 4. Flour yield and grain volume weight from environment $\times$ nitrogen interaction means of winter wheat in Nebraska

\begin{tabular}{lllll} 
& \multicolumn{2}{c}{ Flour yield } & \multicolumn{2}{c}{ Grain volume weight } \\
Environment $^{\mathrm{a}}$ & $\mathrm{N} 0^{\mathrm{b}}$ & $\mathrm{N} 1$ & $\mathrm{~N} 0$ & $\mathrm{~N} 1$ \\
\hline ARF14 & $654.1 \mathrm{~cd}$ & $651.9 \mathrm{~cd}$ & $79.3 \mathrm{a}$ & $79.7 \mathrm{a}$ \\
HPAL14 & $648.4 \mathrm{~d}$ & $665.3 \mathrm{bc}$ & $75.6 \mathrm{~b}$ & $75.6 \mathrm{~b}$ \\
ARF15 & $679.8 \mathrm{ab}$ & $674.7 \mathrm{ab}$ & $74.6 \mathrm{cb}$ & $72.8 \mathrm{c}$ \\
HPAL15 & $684.8 \mathrm{a}$ & $674.2 \mathrm{ab}$ & $76.5 \mathrm{~b}$ & $76.3 \mathrm{~b}$ \\
\hline
\end{tabular}

a. ARF, Agronomy Research Farm, Lincoln, NE, USA; HPAL, High Plains Agricultural Laboratory, Sidney, NE, USA, in 2014 and 2015.

b. Nitrogen rates: $\mathrm{N} 0,0 \mathrm{~kg} \mathrm{~N} \mathrm{ha}^{-1} ; \mathrm{N} 1,34 \mathrm{~kg} \mathrm{~N} \mathrm{ha}^{-1}$. Means followed by the same letter in a given column or row for a trait are not significantly different at $P<0.05$ according to Fisher's LSD test. effect of seeding rate was explained further. Increasing seeding 
all environments (Table 4). This result was in contrast to some studies that found a decrease in grain volume weight with increased application of N. ${ }^{11,12}$ The reason behind this contradictory result could be the inclusion of relatively different genotypes under study, time and type of $\mathrm{N}$ applied as well as environmental variation.

Significant environment $\times$ seeding rate $\times$ genotype interactions were observed for grain volume weight (Table 1) mainly due to change in magnitude across environments (Table 5). All genotypes across environments had no significant improvement in the grain volume weight due to seeding rate, except for Pronghorn, Robidoux and Settler CL at ARF15 (Table 5). Pronghorn, Robidoux and Settler CL had increased grain volume weight with increase in seeding rate from half to twice the recommended rate at ARF15.

Table 5. Grain volume weight from environment $\times$ seeding rate $\times$ genotype interaction means of winter wheat in Nebraska

\begin{tabular}{|c|c|c|c|c|c|}
\hline \multirow[b]{2}{*}{ Genotype } & \multirow[b]{2}{*}{ Seeding rate ${ }^{a}$} & \multicolumn{4}{|c|}{ Environment } \\
\hline & & ARF14 & ARF15 & HPAL14 & HPAL15 \\
\hline \multirow[t]{3}{*}{ Freeman } & Half & $76.8 \mathrm{a}-$ I $^{\ddagger}$ & $74.0 \mathrm{kl}$ & $75.9 d-1$ & $76.8 a-1$ \\
\hline & Recommended & $78 a-k$ & $75.4 \mathrm{e}-1$ & $75.1 \mathrm{~h}-\mathrm{I}$ & $76.3 b-1$ \\
\hline & Twice & $78.3 a-k$ & $75.7 \mathrm{~d}-\mathrm{I}$ & $75.2 \mathrm{e}-1$ & $77 a-1$ \\
\hline \multirow[t]{3}{*}{ Millennium } & Half & $79.9 a-f$ & $77.2 \mathrm{a}-1$ & $76.1 \mathrm{~b}-\mathrm{I}$ & $76.6 \mathrm{~b}-1$ \\
\hline & Recommended & $79.9 a-g$ & $79.4 a-i$ & $76.2 \mathrm{~b}-\mathrm{I}$ & 77.3a-1 \\
\hline & Twice & $80.3 a-d$ & $80.0 a-f$ & $76 c-1$ & $75.6 \mathrm{~d}-1$ \\
\hline \multirow[t]{3}{*}{ Overland } & Half & $78.9 a-j$ & $74.4 \mathrm{j}-1$ & $75.4 \mathrm{e}-1$ & $77.7 a-1$ \\
\hline & Recommended & $79.7 a-h$ & $78.8 a-j$ & $75.3 \mathrm{e}-1$ & $76.6 b-$ \\
\hline & Twice & 79.4a-i & $78.9 a-j$ & $75.3 \mathrm{e}-1$ & $75.6 \mathrm{~d}-1$ \\
\hline \multirow[t]{3}{*}{ Pronghorn } & Half & 80.0a-e & 64.80 & $75.8 \mathrm{~d}-1$ & $76.4 b-$ \\
\hline & Recommended & $80.7 a-c$ & $74.2 j-1$ & $76.3 b-1$ & $76.6 \mathrm{~b}-1$ \\
\hline & Twice & $81.6 a$ & $75.5 \mathrm{~d}-\mathrm{I}$ & $74.8 \mathrm{i}-1$ & $76.7 a-1$ \\
\hline \multirow[t]{3}{*}{ Robidoux } & Half & $77.2 \mathrm{a}-1$ & $58.0 p$ & $75.9 c-1$ & $75.6 \mathrm{~d}-1$ \\
\hline & Recommended & $79.0 \mathrm{a}-\mathrm{j}$ & $69.4 \mathrm{~nm}$ & $75.2 \mathrm{e}-1$ & $76.7 b-1$ \\
\hline & Twice & $79.3 a-i$ & $72.9 \mathrm{Im}$ & $75.1 \mathrm{~g}-1$ & $75.8 \mathrm{~d}-1$ \\
\hline \multirow[t]{3}{*}{ Settler CL } & Half & $80.3 a-d$ & $67.9 \mathrm{no}$ & $75.8 \mathrm{~d}-1$ & $75.4 \mathrm{e}-1$ \\
\hline & Recommended & $80.9 a b$ & $75.0 \mathrm{~h}-\mathrm{I}$ & $75.5 \mathrm{~d}-1$ & $76.6 b-1$ \\
\hline & Twice & $80.9 a b$ & $75.8 \mathrm{~d}-1$ & $75.6 \mathrm{~d}-1$ & $75.7 \mathrm{~d}-1$ \\
\hline
\end{tabular}

a. Seeding rate: half, 93 and 126 seeds $\mathrm{m}^{-2}$; recommended, 186 seeds and 252 seeds $\mathrm{m}^{-2}$; twice, 372 and 504 seeds $\mathrm{m}^{-2}$, respectively, at HPAL (High Plains Agricultural Laboratory, Sidney, NE, USA) and ARF (Agronomy Research Farm, Lincoln, NE, USA) in 2014 and 2015. Means followed by the same letter in a given column or row are not significantly different at $P<0.05$ according to Fisher's LSD test.

Note: a-l, a through I in a sequence of abcdfghijkl, and similarly for others. 
Settler CL had increased grain volume weight with increased seeding rate up to the recommended seeding rate, but with no increase between the recommended and twice the recommended rate at ARF15. This result was similar to previous findings where grain volume weight increased with increase in seeding rate from $65 \mathrm{~kg} \mathrm{ha}^{-1}\left(245\right.$ seeds $\mathrm{m}^{-2}$ ) to $130 \mathrm{~kg} \mathrm{ha}^{-1}$ (489 seeds $\left.\mathrm{m}^{-2}\right) .{ }^{4}$ The increase in grain volume weight may be due to production of a lower number of harvestable tillers and larger grains, produced by early tillers, at higher seeding rate. ${ }^{4}$

\section{Mixograph parameters}

No significant interactions were detected between seeding rate and genotype for the selected Mixograph parameters (Table 1), indicating that similar performance of genotypes was obtained for all Mixograph parameters with change in seeding rate. These results were similar to previous results. ${ }^{4,5}$

\section{Resistance to dough extension}

Resistance to dough extension was significantly affected by environment, $\mathrm{N}$, seeding rate, genotype, environment $\times$ genotype, $\mathrm{N} \times$ genotype, $\mathrm{N} \times$ seeding rate, and environment $\times \mathrm{N} \times$ genotype (Table 1 ).

A significant $\mathrm{N} \times$ seeding rate interaction was observed for resistance to dough extension (Table 1), mainly due to increase in resistance to dough extension from twice seeding rate and no $\mathrm{N}$ application (Table 6). $\mathrm{N}$ application at the flag leaf stage slightly increased resistance to dough extension for half and recommended seeding rate, whereas a significant increase was observed at twice the recommended seeding rate compared to no $\mathrm{N}$ application (Table 6).

Table 6. Resistance to dough extension and dough strength from nitrogen $\times$ seeding rate interaction means of winter wheat in Nebraska

\begin{tabular}{|c|c|c|c|c|}
\hline \multirow[b]{2}{*}{ Seeding rate ${ }^{a}$} & \multicolumn{2}{|c|}{ Resistance to dough extension } & \multicolumn{2}{|c|}{ Dough strength } \\
\hline & NOb & N1 & No & N1 \\
\hline Half & $337.6 a b$ & $345.0 a$ & $47.5 a b$ & $48.7 a$ \\
\hline Recommended & $330.6 b c$ & $338.5 a b$ & $46.5 b c$ & $47.8 a b$ \\
\hline Twice & $323.6 c$ & $341.6 a$ & $45.4 c$ & $48.2 \mathrm{a}$ \\
\hline
\end{tabular}

a. Seeding rate: half, 93 and 126 seeds $\mathrm{m}^{-2}$; recommended, 186 seeds and 252 seeds $\mathrm{m}^{-2}$; twice, 372 seeds and 504 seeds $\mathrm{m}^{-2}$, respectively, at HPAL (High Plains Agricultural Laboratory, Sidney, NE, USA) and ARF (Agronomy Research Farm, Lincoln, NE, USA).

b. Nitrogen rates: $\mathrm{N} 0,0 \mathrm{~kg} \mathrm{~N} \mathrm{ha}^{-1} ; \mathrm{N} 1,34 \mathrm{~kg} \mathrm{~N} \mathrm{ha}^{-1}$. Means followed by the same letter in a given column or row for a trait. 
Significant interactions of environment $\times \mathrm{N} \times$ genotype were observed for resistance to dough extension (Table 1), mainly due to change in magnitude of genotype across environments with the application of $\mathrm{N}$ (Table 7). N application slightly increased resistance to dough extension for all genotypes in all environments, except for Overland at HPAL14 and ARF15, and Pronghorn at ARF15 (Table 7). Resistance to dough extension significantly varied with environment, ranging from320 (ARF14) to $364 \%$ TQ $\times$ min (HPAL14) on average (Table 7), with higher values indicating higher resistance to extension of dough. Resistance to dough extension was higher at HPAL14 compared to other environments (Table 7).

\section{Dough strength}

Dough strength was significantly affected by environment, $\mathrm{N}$, seeding rate, genotype, environment $\times$ genotype, environment $\times$ seeding rate, $\mathrm{N} \times$ genotype, $\mathrm{N} \times$ seeding rate, and environment $\times \mathrm{N} \times$ genotype (Table 1 ).

Table 7. Resistance to dough extension, dough strength, dough development time and mixing tolerance from environment $x$ nitrogen $\times$ genotype interaction means of winter wheat in Nebraska.

$$
\begin{array}{llll}
\text { Freeman } & \text { Millennium } & \text { Overland } & \text { Pronghorn }
\end{array}
$$

\begin{tabular}{|c|c|c|c|c|c|c|c|c|c|c|c|c|c|}
\hline Trait & Environmen & tt $\mathrm{NO}^{\mathrm{a}}$ & N1 & No & N1 & No & $\mathrm{N} 1$ & No & N1 & No & $\mathrm{N} 1$ & No & N1 \\
\hline \multirow[t]{4}{*}{$\mathrm{RDE}$} & ARF14 & $286.6 \mathrm{i}$ & $295.9 \mathrm{~g}-\mathrm{i}$ & $330.2 a-i$ & $348.9 a-i$ & $342.1 \mathrm{a}-\mathrm{i}$ & 351.0a-i & $308.1 \mathrm{~d}-\mathrm{i}$ & $325.0 a-i$ & $298.5 f-i$ & $311.6 c-i$ & $314.7 a-i$ & 331.9a-i \\
\hline & HPAL14 & $340.6 a-i$ & $359.2 \mathrm{a}-\mathrm{g}$ & $374.0 \mathrm{a}-\mathrm{c}$ & $376.1 \mathrm{ab}$ & $377.8 a$ & $372.6 a-c$ & $356.6 a-i$ & $368.9 a-d$ & $348.9 a-i$ & $360.8 a-f$ & 363.0a-e & 363.4a-e \\
\hline & ARF15 & $301.2 \mathrm{e}-\mathrm{i}$ & $342.5 a-i$ & 333.2a-i & 349.1a-i & $341.4 a-i$ & $327.8 \mathrm{a}-\mathrm{i}$ & $305.9 d-i$ & 294.6hi & $316.2 a-i$ & $333.5 a-i$ & $331.0 a-i$ & $335.6 a-i$ \\
\hline & HPAL15 & $312.4 b-i$ & 333.6a-i & $332.4 a-i$ & $346.9 a-i$ & 338.0a-i & 349.7a-i & $320.3 a-i$ & 343.7a-i & $325.7 a-i$ & 331.0a-i & $335.0 \mathrm{a}-\mathrm{i}$ & $347.1 a-i$ \\
\hline \multirow[t]{4}{*}{ DS } & ARF14 & $40.9 f$ & $42.2 d-f$ & $46.4 a-f$ & 49.3a-f & $48.1 a-f$ & $49.9 a-f$ & $45.1 a-f$ & $47.5 a-f$ & $42.0 e-f$ & $44.0 c-f$ & $45.4 a-f$ & $48.4 a-f$ \\
\hline & HPAL14 & $49.0 a-f$ & 51.7a-e & $53.6 a-c$ & $53.8 \mathrm{ab}$ & $54.7 a$ & 54.0ab & $51.8 a-d$ & $53.8 a-c$ & $49.3 a-f$ & 51.5a-e & $52.8 a-c$ & $53.1 \mathrm{a}-\mathrm{c}$ \\
\hline & ARF15 & $41.1 \mathrm{f}$ & $47.1 \mathrm{a}-\mathrm{f}$ & $45.9 a-f$ & $48.1 a-f$ & $47.0 a-f$ & $45.1 \mathrm{a}-\mathrm{f}$ & $42.2 \mathrm{~d}-\mathrm{f}$ & $40.2 f$ & $43.0 d-f$ & $45.3 a-f$ & $46.1 \mathrm{a}-\mathrm{f}$ & $46.5 a-f$ \\
\hline & HPAL15 & $43.0 \mathrm{~d}-\mathrm{f}$ & $46.2 a-f$ & $45.6 a-f$ & 48.0a-f & $46.3 a-f$ & 48.9a-f & $44.3 d-f$ & $48.1 a-f$ & $44.4 b-f$ & $46.1 a-f$ & 47.3a-f & $48.7 a-f$ \\
\hline \multirow[t]{4}{*}{ DDT } & ARF14 & $6.9 a$ & $6.8 a$ & $3.9 \mathrm{i}-\mathrm{r}$ & $3.71-r$ & $3.1 p-r$ & 3.0r & $6.0 a-d$ & $5.5 c-f$ & $6.6 a b$ & $6.4 a-c$ & $5.6 \mathrm{~b}-\mathrm{e}$ & $5.3 \mathrm{c}-\mathrm{h}$ \\
\hline & HPAL14 & $5.0 \mathrm{~d}-1$ & $4.4 f-n$ & $4.2 \mathrm{~g}-\mathrm{q}$ & $3.9 \mathrm{i}-\mathrm{r}$ & $3.4 m-r$ & $3.2 p-r$ & $4.7 \mathrm{e}-1$ & $4.5 \mathrm{e}-1$ & $4.4 \mathrm{f}-\mathrm{n}$ & $4.3 f-p$ & $5.1 \mathrm{~d}-\mathrm{i}$ & $5.0 \mathrm{~d}-\mathrm{k}$ \\
\hline & ARF15 & $5.3 c-h$ & $4.4 \mathrm{f}-\mathrm{n}$ & $4.5 \mathrm{e}-1$ & $3.8 j-r$ & $3.3 n-r$ & $3.7 m-r$ & $5.5 b-f$ & $5.1 d-i$ & $4.5 \mathrm{e}-1$ & $3.6 m-r$ & 5.2 & $4.4 \mathrm{f}-\mathrm{n}$ \\
\hline & HPAL15 & $5.0 \mathrm{~d}-\mathrm{k}$ & $4.5 \mathrm{e}-1$ & $3.8 j-r$ & $3.9 \mathrm{i}-\mathrm{r}$ & $3.6 m-r$ & $3.0 r$ & $4.0 \mathrm{i}-\mathrm{r}$ & $3.9 i-r$ & $4.6 \mathrm{e}-1$ & $4.5 \mathrm{e}-1$ & $4.4 \mathrm{f}-\mathrm{n}$ & $4.1 \mathrm{~h}-\mathrm{n}$ \\
\hline \multirow[t]{4}{*}{ MT } & ARF14 & $5.9 a$ & $5.7 a-c$ & $4.4 \mathrm{f}-\mathrm{I}$ & $4.2 \mathrm{~g}-\mathrm{m}$ & $3.8 \mathrm{j}-\mathrm{m}$ & $3.7 \mathrm{k}-\mathrm{m}$ & $5.6 a-e$ & $5.4 a-f$ & $5.7 a-d$ & $5.8 a b$ & $5.4 a-f$ & $5.2 \mathrm{a}-\mathrm{g}$ \\
\hline & HPAL14 & 5.1a-h & $4.8 b-j$ & $4.4 \mathrm{f}-1$ & $4.1 \mathrm{~h}-\mathrm{I}$ & $3.8 \mathrm{k}-\mathrm{m}$ & $3.6 \mathrm{~lm}$ & $4.9 a-i$ & $4.9 a-i$ & $4.9 a-i$ & $4.7 \mathrm{~d}-\mathrm{k}$ & $5.1 a-h$ & $5.1 \mathrm{a}-\mathrm{h}$ \\
\hline & ARF15 & 5.1a-h & $4.5 f-1$ & $4.3 \mathrm{~g}-1$ & $4.2 \mathrm{~g}-\mathrm{m}$ & $3.8 \mathrm{k}-\mathrm{m}$ & $3.8 \mathrm{k}-\mathrm{m}$ & 5.1a-h & $4.6 \mathrm{~d}-\mathrm{k}$ & $4.7 d-k$ & $3.9 \mathrm{i}-\mathrm{m}$ & $4.6 \mathrm{~d}-\mathrm{k}$ & $4.5 f-1$ \\
\hline & HPAL15 & $4.8 b-j$ & $4.5 f-1$ & $4.2 \mathrm{~g}-\mathrm{m}$ & $4.0 \mathrm{i}-\mathrm{m}$ & $4.1 \mathrm{~h}-\mathrm{I}$ & $3.2 \mathrm{~m}$ & $4.3 \mathrm{~g}-1$ & $4.3 \mathrm{~g}-1$ & $4.8 b-j$ & $4.6 \mathrm{~d}-\mathrm{k}$ & $4.5 f-1$ & $4.4 \mathrm{f}-\mathrm{I}$ \\
\hline
\end{tabular}

a. Nitrogen rates: N0, $0 \mathrm{~kg} \mathrm{~N} \mathrm{ha}^{-1} ; \mathrm{N} 1,34 \mathrm{~kg} \mathrm{~N} \mathrm{ha}^{-1}$ at HPAL (High Plains Agricultural Laboratory, Sidney, NE, USA) and ARF (Agronomy Research Farm, Lincoln, NE, USA) in 2014 and 2015.

$\mathrm{RDE}$, resistance to dough extension (\%TQ $\times$ min, where TQ is torque); DS, dough strength (\%); DDT, dough development time (min); MT, mixing tolerance (0-7).

Means followed by the same letter in a given column or row for a trait are not significantly different at $P<0.05$ according to Fisher's LSD test. Note: a-i, a through i in a sequence of abcdefghi, and similarly for others. 
A significant $\mathrm{N} \times$ seeding rate interaction was observed for dough strength (Table 1), mainly due to increase in dough strength from twice seeding rate when no $\mathrm{N}$ applied (Table 6). $\mathrm{N}$ application at the flag leaf slightly increased dough strength for half and recommended seeding rate, whereas a significant increase was observed at twice the recommended seeding rate (Table 6) compared to no $\mathrm{N}$ applied. These results were similar to previous results, ${ }^{15}$ where increased dough strength due to $\mathrm{N}$ application was found.

Significant environment $\times \mathrm{N} \times$ genotype interactions were observed for dough strength (Table 1), mainly due to change in magnitude of genotype across environments with the application of N (Table 7). Dough strength was higher at HPAL14 compared to other environments. $\mathrm{N}$ application slightly increased dough resistance for all genotypes in all environments, except for Overland at HPAL14 and ARF15, and Pronghorn at ARF15 (Table 7).

\section{Dough development time}

Dough development time was significantly affected by environment, $N$, seeding rate, genotype, environment $\times$ genotype, environment $\times$ seeding rate, environment $\times \mathrm{N} \times$ genotype, and environment $\times \mathrm{N} \times$ seeding rate (Table 1).

Significant environment $\times \mathrm{N} \times$ genotype interactions were observed for dough development time (Table 1), mainly due to change in magnitude of genotype due to different $\mathrm{N}$ treatments across environments (Table 7). No significant improvement was observed in dough development time due to $\mathrm{N}$ in all environment (Table 7). Dough development time was higher for Freeman (4.4-6.9 min), Pronghorn (3.9-5.7 min), Robidoux (4.1-6.5 min) and Settler CL (4.2-5.5 min) compared to Overland (3-3.5min) and Millennium (3.8$4.2 \mathrm{~min}$ ) in all environments and $\mathrm{N}$ treatments (Table 7).

Significant environment $\times \mathrm{N} \times$ seeding rate interactions were observed for dough development time (Table 1), mainly due to decrease in dough development time with increase in seeding rate in two environments (ARF14 and ARF15) when no $\mathrm{N}$ was applied and also due to change in magnitude across environments (Table 8). Dough development time was not significantly decreased with the change in $\mathrm{N}$ application rate and seeding rate in three environments, except for ARF15 (Table 8). The result of no significant increase in dough development time with increase in seeding rate was contrary to previous research. ${ }^{4,5}$ This contradictory result may be due to the inclusion of different genotypes across different environments. 
Table 8. Dough development time from environment $\times$ nitrogen $\times$ seeding rate interaction means of winter wheat in Nebraska.

\begin{tabular}{|c|c|c|c|c|c|c|c|c|}
\hline \multirow{3}{*}{ Seeding rate } & \multicolumn{8}{|c|}{ Environment } \\
\hline & \multicolumn{2}{|c|}{ ARF14 } & \multicolumn{2}{|c|}{ HPAL14 } & \multicolumn{2}{|c|}{ ARF15 } & \multicolumn{2}{|c|}{ HPAL15 } \\
\hline & $\mathrm{N} 0^{\mathrm{b}}$ & N1 & NO & N1 & No & N1 & No & N1 \\
\hline Half & $5.0 \mathrm{~b}-\mathrm{e}$ & $4.8 b-f$ & $4.3 e-g$ & $4.3 e-g$ & $4.3 e-g$ & $4.0 f g$ & $4.4 \mathrm{e}-\mathrm{g}$ & $3.7 \mathrm{~g}$ \\
\hline Recommended & $5.3 \mathrm{ab}$ & $5.2 a-d$ & $4.5 b-g$ & $4.2 \mathrm{e}-\mathrm{g}$ & $4.6 \mathrm{~b}-\mathrm{g}$ & $4.2 \mathrm{e}-\mathrm{g}$ & $3.9 \mathrm{fg}$ & $4.0 \mathrm{fg}$ \\
\hline Twice & $5.7 a$ & $5.3 \mathrm{ab}$ & $4.5 \mathrm{bg}$ & $4.1 \mathrm{e}-\mathrm{g}$ & $5.3 a b$ & $4.4 \mathrm{e}-\mathrm{g}$ & $4.4 \mathrm{e}-\mathrm{g}$ & $4.1 \mathrm{e}-\mathrm{g}$ \\
\hline
\end{tabular}

a Seeding rate: half, 93 and 126 seeds $\mathrm{m}^{-2}$; recommended, 186 and 252 seeds $\mathrm{m}^{-2}$; twice, 372 and 504 seeds $\mathrm{m}^{-2}$, respectively, at HPAL (High Plains Agricultural Laboratory, Sidney, NE) and ARF (Agronomy Research Farm, Lincoln, NE) in 2014 and 2015.

${ }^{b}$ Nitrogen rates: N0, $0 \mathrm{~kg} \mathrm{~N} \mathrm{ha}^{-1} ; \mathrm{N} 1,34 \mathrm{~kg} \mathrm{~N} \mathrm{ha}^{-1}$.

Means followed by the same letter in a given column or row are not significantly different at $P<0.05$ according to Fisher's LSD test.

Note: $b-e, b$ through e in a sequence of bcde, and similarly for others.

\section{Mixing tolerance}

Mixing tolerance was significantly affected by environment, $\mathrm{N}$, seeding rate, genotype, environment $\times$ genotype, environment $\times \mathrm{N}$, and environment $\times$ $\mathrm{N} \times$ genotype (Table 1 ).

No significant environment $\times$ seeding rate was observed for mixing tolerance, implying that response of seeding rate was similar across environments. Mixing tolerance increased with increasing seeding rates from half ( $4.5 \mathrm{~min}$ ) to twice $(4.7 \mathrm{~min})$ the recommended seeding rates. This result was contradictory to previous research, where mixing tolerance increased with decreased seeding rates from $130 \mathrm{~kg} \mathrm{ha}^{-1}$ (489 seeds $\mathrm{m}^{-2}$ ) to $65 \mathrm{~kg} \mathrm{ha}^{-1}$ (245 seeds $\left.\mathrm{m}^{-2}\right) .4,5$

Significant environment $\times \mathrm{N} \times$ genotype interactions were observed for mixing tolerance (Table 1), mainly due to change in rank and magnitude of genotype across and within environments (Table 7). No significant decrease was observed on mixing tolerance due to $\mathrm{N}$ in all environment (Table 7). Mixing tolerance was higher for Freeman (4.7-5.8), Pronghorn (4.3-5.5), Robidoux (4.3-5.7) and Settler CL (4.5-5.3) compared to Overland (3.6-3.8) and Millennium (4.1-4.3) in all environments and $\mathrm{N}$ treatments (Table 7).

Although grain protein content, flour yield, grain volume weight and Mixograph parameters varied with environments, all genotypes under study have preferred end-use quality. According to Baenziger et al., ${ }^{28}$ preferred end-use quality of wheat has grain protein content $\geq 120 \mathrm{~g} \mathrm{~kg}^{-1}$, dough development time $\geq 3 \mathrm{~min}$ and mixing tolerance $\geq 3$. Therefore, all genotypes 
grown at twice the recommended seeding rate and top-dressed $\mathrm{N}$ at the flag leaf stage meet the criteria of better end-use quality without sacrificing the highest grain yield obtained. ${ }^{20}$

\section{Conclusions}

In this study, end-use quality traits were influenced by genotype, environment, seeding rate and top-dressed $\mathrm{N}$ at the flag leaf stage, and their interactions. Significant genotype $\times$ environment interaction was observed for all traits under study. Therefore, the choice of production environment and genotype are critical in optimizing the end-use quality of wheat.

Although grain protein content was correlated with other traits, no single trait was effectively a predictor of end-use quality, and combinations of traits are required to estimate end-use quality. Mixograph parameters had a strong correlation with grain volume weight and flour yield. This indicates that selection of Mixograph parameters should be effective for better end-use quality and improved grain yield. This result suggested that plant breeders could focus on improving Mixograph parameters for better enduse quality of wheat.

The key finding of this research is that increasing seeding rates up to double the current recommendations with supplemental top-dressed $\mathrm{N}$ at the flag leaf stage improved most of the end-use quality traits of hard red winter wheat without sacrificing grain yield ${ }^{20}$ for the location tested in $\mathrm{Ne}$ braska. Even though increased seeding rate decreased grain protein content, the drop-in protein content was compensated for by the application of $\mathrm{N}$ at the flag leaf stage. This will have a significant effect on the premium for protein a farmer could receive when marketing wheat. All genotypes grown at twice the recommended seeding rate and top-dressed $\mathrm{N}$ at the flag leaf stage meet the criteria of better end-use quality.

\section{References}

1 Hussain MI, Shah SH, Hussain S and lqbal K, Growth yield and quality response of three wheat (Triticum aestivum L.) varieties to different levels of $\mathrm{N}, \mathrm{P}$, and $\mathrm{K}$. Int J Agric Biol 4:362-364 (2002).

2 Vocke $G$ and Liefert O, United States Department of Agriculture Economic Research Service - Wheat background. Online http://www.ers.usda.gov/ topics/crops/wheat/background/.aspx [10 July 2015].

3 Peterson CJ, Graybosch RA, Shelton DR and Baenziger PS, Baking quality of hard winter wheat: response of cultivars to environment in the Great Plains. Euphytica 100:157-162 (1998). 
4 Geleta B, Atak M, Baenziger PS, Nelson LA, Baltensperger DD, Eskridge KM et al., Seeding rate and genotype effect on agronomic performance and enduse quality of winter wheat. Crop Sci 42:827-832 (2002).

5 Xue Q, Weiss A, Baenziger PS and Shelton DR, Seeding rate and genotype affect yield and end-use quality in winter wheat. J Agron Crop Sci 2:18-25 (2011).

6 Haile D, Nigussie-Dechassa R, Abdo W, and Girma F, Seeding rate and genotype effects on agronomic performance and grain protein content of durum wheat [Triticum turgidum L. Var. Durum] in southeastern Ethiopia. Afr J Food Agric Nutr Dev 13:7693-7710 (2013).

7 Tompkins DK, Fowler DB and Wright AT, Water use by no-till winter wheat influence of seed rate and row spacing. Agron J 83:766-769 (1991).

8 Chen C, Neill K, Wichman D and Westcott M, Hard red spring wheat response to row spacing, seeding rate, and nitrogen. Agron J 100:1296-1302 (2008).

9 Lloveras J, Manent J, Viudas J, López A and Santiveri P, Seeding rate influence on yield and yield components of irrigated winter wheat in a Mediterranean climate. Agron J 96:1258-1265 (2004).

10 Fageria NK and Baligar VC, Enhancing nitrogen use efficiency in crop plants. Adv Agron 88:97-185 (2005).

11 Otteson BN, Mergoum M and Ransom JK, Seeding rate and nitrogen management effects on spring wheat yield and yield components. Agron J 99:1615-1621 (2007).

12 Saint Pierre C, Peterson CJ, Ross AS, Ohm JB, Verhoeven MC, Larson M et al., Winter wheat genotypes under different levels of nitrogen and water stress: changes in grain protein composition. J Cereal Sci 47:407-416 (2008).

13 Tea I, Genter T, Naulet N, Lummerzheim M and Kleiber D, Interaction between nitrogen and sulfur by foliar application and its effects on flour bread-making quality. J Sci Food Agric 87:2853-2859 (2007).

14 Gauer LE, Grant CA, Gehl DT and Bailey LD, Effects of nitrogen fertilization on grain protein content, nitrogen uptake, and nitrogen use efficiency of six spring wheat (Triticum aestivum L.) cultivars, in relation to estimated moisture supply. Can J Plant Sci 72:235-241 (1992).

15 Guttieri MJ, McLean R, Stark JC and Souza E, Managing irrigation and nitrogen fertility of hard spring wheats for optimum bread and noodle quality. Crop Sci 45:2049-2059 (2005).

16 Mullen RW, Freeman KW, Raun WR, Johnson GV, Stone ML and Solie JB, Identifying an in-season response index and the potential to increase wheat yield with nitrogen. Agron J 95:347-351 (2003).

17 Gooding MJ, Gregory PJ, Ford KE and Ruske RE, Recovery of nitrogen from different sources following applications to winter wheat at and after anthesis. Field Crop Res 100:143-154 (2007).

18 Finney KF, Yamazaki WT, Youngs VL and Rubenthaler GL, Quality of hard, soft, and durum wheats, in Wheat and Wheat Improvement. American Society of Agronomy, Madison, WI, pp. 677-748 (1987). 
19 Johansson E, Prieto-Linde ML and Jönsson JÖ, Effects of wheat cultivar and nitrogen application on storage protein composition and breadmaking quality. Cereal Chem 78:19-25 (2001).

20. Bhatta M, Eskridge KM, Rose DJ, Santra DK, Baenziger PS and Regassa T, Seeding rate, genotype, and top-dressed nitrogen effects on yield and agronomic characteristics of winter wheat. Crop Sci 57:951-963 (2017).

21 Poudel R, Bhatta M, Regassa T and Rose $D$, Influence of foliar fungicide treatment on lipolytic enzyme activity of whole wheat. Cereal Chem 94:633639 (2017).

22 AACC International, in Approved Methods of Analysis. AACC International, St Paul, MN. Online http://methods.aaccnet.org/toc.aspx [10 July 2015].

23 SAS Institute, SAS 9.4 Product documentation. Online http://support.sas.com/ documentation/94/index.html [10 July 2015].

24 Peterson CJ, Graybosch RA, Baenziger PS and Grombacher AW, Genotype and environment effects on quality characteristics of hard red winter wheat. Crop Sci 32:98-103 (1992).

25 Rozbicki J, Cegli A, Gozdowski D, Jakubczak M, Cacak-Pietrzak G, Madry Wet al., Influence of the cultivar, environment and management on the grain yield and bread-making quality in winter wheat. J Cereal Sci 61:126-132 (2015).

26 Martinant JP, Nicolas Y, Bouguennec A, Popineau Y, Saulnier L and Branlard $G$, Relationships between Mixograph parameters and indices of wheat grain quality. J Cereal Sci 27:179-189 (1998).

27 Otteson BN, Mergoum M and Ransom JK, Seeding rate and nitrogen management on milling and baking quality of hard red spring wheat genotypes. Crop Sci 48:749-755 (2008).

28 Baenziger PS, Shelton DR, Shipman MJ and Graybosch RA, Breeding for enduse quality: reflections on the Nebraska experience. Euphytica 119:95-100 (2001). 